\title{
Editorial
}

\section{Development of secondary polycythaemia in chronic airways obstruction}

Much has been written about the appropriateness or otherwise of secondary polycythaemia in patients with chronic airways obstruction (CAWO), and it is common clinical experience that not all such patients have a raised haemoglobin. Some authors have argued for a predominantly subnormal red cell mass response ${ }^{1-7}$ to a given degree of hypoxia and others for normal ${ }^{8-15}$ or even excessive responses. ${ }^{16}$ Indeed the justification for phlebotomy in secondary polycythaemia is sometimes based on attempted judgments as to the "appropriateness" or "excess" of red cell mass response. ${ }^{17}$ These arguments are based on certain assumptions that are open to question and therefore merit discussion.

\section{What is the normal haemopoietic response to hypoxaemia?}

An increased oxygen carrying capacity in the blood of animals acclimatised to the hypoxic conditions of high altitude was first recorded by Paul Bert. ${ }^{18}$ Early work on this phenomenon, before red cell mass (RCM) estimations by chromium 51, was extensively reviewed by Hurtado in $1945 .{ }^{19}$ Haematocrits and haemoglobins were the usual meaurements of the red cell response. The subjects were generally Andean residents whose health, smoking, and nutritional status were not assessed. However, much useful information was gained and is embodied in Hurtado's classic diagram (fig 1). Note that arterial oxygen saturation $\left(\mathrm{SaO}_{2}\right)$ is taken as the measure of hypoxaemia.

Until 1968 all articles on the polycythaemia of CAWO used these results to assess appropriateness. For example, Vanier ${ }^{5}$ concluded that there was a subnormal response though she made the error of directly comparing Hurtado's results, using dyes, with $\mathrm{Cr}^{51}$ methods for RCM estimation. Dye methods (vital red and Evans blue) give values for RCM about $35 \%$ higher than the $\mathrm{Cr}^{51}$ method. ${ }^{19} 20$ In retrospect her patients probably had "normal" responses. Shaw ${ }^{9}$ and Hume ${ }^{11}$ circumvented this problem by comparing percentage of sea level values and concluded that there was a normal RCM response but diminished rises in haemoglobin and

Address for reprint requests: Dr JR Stradling, The Churchill Hospital, Headington, Oxford OX3 $7 \mathrm{LJ}$. haematocrit, because of plasma expansion, in patients hypoxic from CAWO. This latter observation also appeared to explain why other authors, measuring only haemoglobin and haematocrit, had concluded that responses were subnormal. ${ }^{13}$

Weil and colleagues ${ }^{14}$ in 1968 published some important reference data on haemoglobin, haematocrit, and RCM in healthy Caucasians at altitude. Their data collected at three different altitudes and therefore at varying arterial saturations were presented as a linear relationship between RCM $(\mathrm{ml} / \mathrm{kg})$ and $\mathrm{SaO}_{2}$ with $95 \%$ confidence limits for the individual results (fig 2). There are three points in their analysis which merit comment. Firstly, the three groups were dissimilar in one important respect, that of obesity. The mean Quetelec index of obesity $\left(\mathrm{W} / \mathrm{H}^{2}\right)$ was significantly higher in the 1600 metre than in the 3100 metre residents $(25 \cdot 4 \pm 1 \cdot 73(\mathrm{SD})$ and $23 \cdot 6 \pm 2 \cdot 35$ respectively, $\mathrm{p}<0.01$ ). Thus when $\mathrm{RCMs}$ are quoted as $\mathrm{ml} / \mathrm{kg}$ the slope of the $\mathrm{RCM} / \mathrm{SaO}_{2}$ relationship is altered falsely. Secondly, the $\mathrm{RCM} / \mathrm{SaO}_{2}$ relationship is not a straight line. The sea level and 1600 metre residents have mean saturations of $96.4 \pm 0.5 \%$

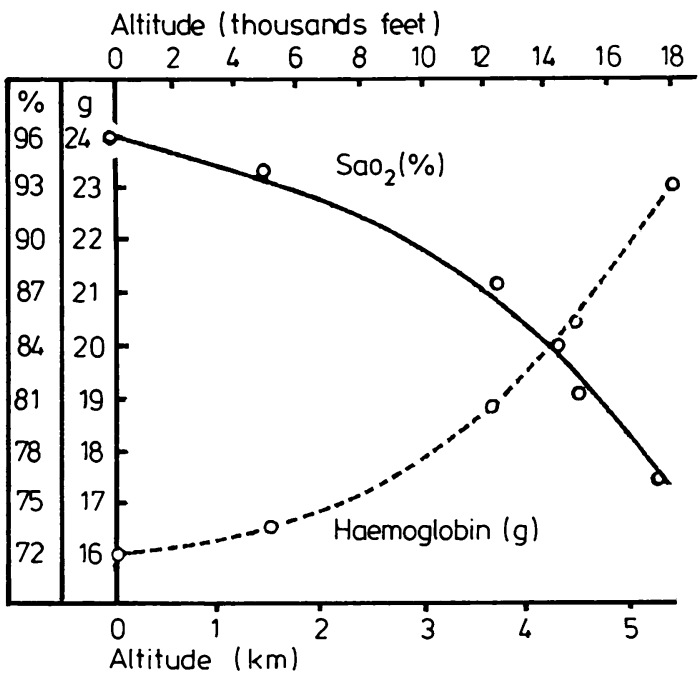

Fig 1 Correlation between concentration of haemoglobin in peripheral blood and percentage arterial oxygen saturation at various altitudes (from reference 19). 


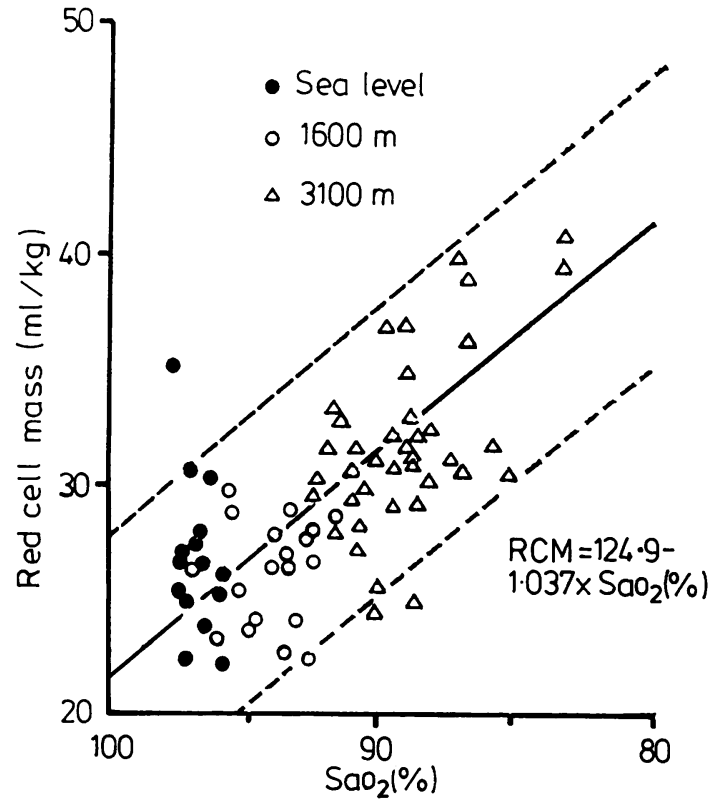

Fig 2 Red cell mass $/ \mathrm{SaO}_{2}$ relationship in normal men residing at sea level, 1600 , and $3100 \mathrm{~m}$. Broken lines represent $95 \%$ confidence limits on individual estimates.

(SD) and $93.9 \pm 1.4 \%$ respectively $(\mathrm{p}=<0.001)$, while their RCMs (\% predicted normal ${ }^{20}$ ) are $96 \cdot 1 \pm 11.5 \%$ (SD) and $94 \cdot 8 \pm 7 \cdot 9 \%$ respectively $(\mathrm{p}=<0.5)$. Hence a significant fall in $\mathrm{SaO}_{2}$ was not accompanied by a rise in RCM; the same applied to haematocrit and haemoglobin levels. Accepting these observations, it is logical that a linear relationship should only be drawn through the 3100 metre data and a horizontal line through the rest (fig 3). Residual error is significantly less with this threshold model which predicts no significant rise in RCM until saturations below $92 \%$ have been reached. Included in fig 3 are nine patients with CAWO described in the same paper. Thirdly, the altitude data only extend down to $83 \%$ saturation and should not be used for comparisons below this.

From the British literature, Harrison ${ }^{16}$ found a group of patients with CAWO who had RCM responses which seemed truly "excessive," being well outside the span of Weil's data. Cocking and Darke ${ }^{13}$ also refer to Weil's data but in their group of patients, while most had an apparently normal response, a few had very subnormal responses. Thus there do seem to be some patients who lie well beyond, in both directions, the $95 \%$ confidence limits of Weil's corrected regression line for RCM against $\mathrm{SaO}_{2}$ at altitude. What factors might be responsible for a wider scatter than that observed at altitude?

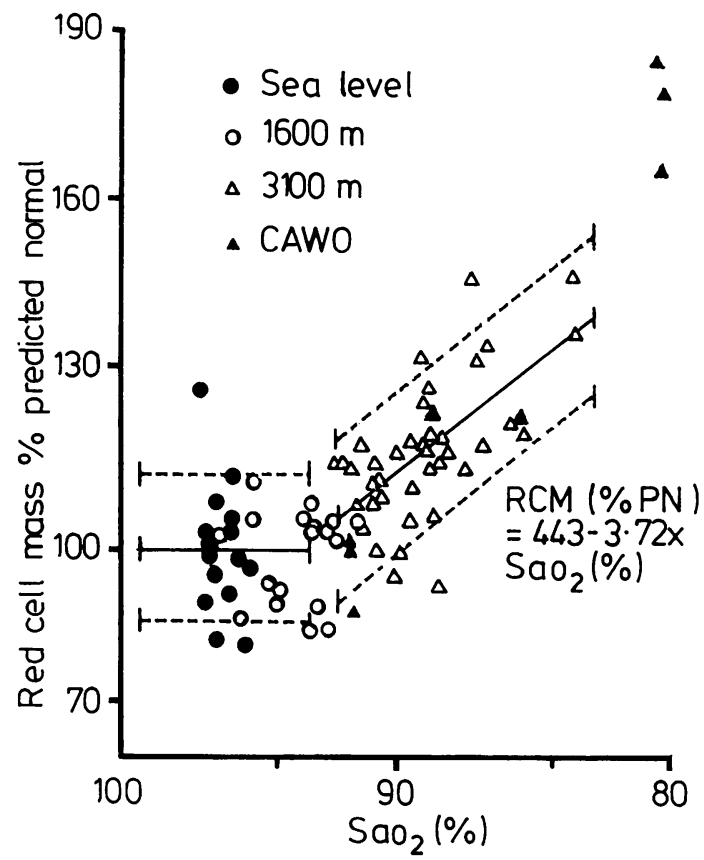

Fig 3 Red cell mass $/ \mathrm{SaO}_{2}$ relationship using percentage predicted normal RCM. Regression of 3100 metre data analysed separately, broken lines represent $95 \%$ confidence limits on individual estimates. Also included are nine patients with CAWO (revised from reference 14).

\section{What is the stimulus and response to erythropoietin secretion?}

Teleologically the function of the erythropoietin control system should be to maintain oxygen delivery to the tissues in the face of diminished oxygen supply. This has to be achieved in the face of both anaemic hypoxaemia and hypoxic hypoxaemia. It is believed that a fall in oxygen tissue tension in the relevant cells in the kidney is ultimately the stimulus responsible for erythropoietin production. ${ }^{21} 22$ This parameter depends on arterial oxygen tension, haemoglobin concentration, the haemoglobin dissociation curve, and renal blood flow: the latter in turn depends on viscosity, blood pressure, and perhaps local vascular tone. Hence it would be naïve to expect erythropoietin secretion to be dependent on just one factor, $\mathrm{SaO}_{2}$. None the less the nearest parameter to "tissue oxygen tension" easily obtainable appears empirically to be the $\mathrm{SaO}_{2} .^{22}$ The response expected from erythropoietin secretion is a restoration of satisfactory oxygen delivery to the tissues. In the face of arterial hypoxaemia the main ways to restore oxygen delivery to normal, thus "satisfying" the erythropoietin secreting cell, are by 
increasing either blood flow or haemoglobin concentration. The response conventionally measured is RCM : but it should be noted that a rise in RCM per se will not improve oxygen delivery unless it increases blood flow or haemoglobin concentration or both. It is unlikely to influence blood flow and if the rise in RCM is accompanied by an equal rise in plasma volume then haemoglobin concentration will stay the same, oxygen delivery would not increase and the erythropoietin cell would not be "satisfied." Conversely, patients on diuretic therapy because of a reduced plasma volume increase the haematocrit and oxygen carrying capacity of the blood without affecting RCM. Despite these reservations and because of the susceptibility of haemoglobin and the haematocrit to temporary day-to-day fluctuations in plasma volume, the RCM is generally taken to be the most consistent indication of the level of stimulation of erythropoietin. ${ }^{22}$ These complex interrelationships are represented diagrammatically in fig 4.

\section{Which arterial saturation?}

Having accepted $\mathrm{SaO}_{2}$ as the easiest guide to tissue oxygen tension under what conditions should it be measured to gauge the hypoxaemic stimulus to erythropoietin production? A single estimation of $\mathrm{SaO}_{2}$ in a patient sitting in hospital or the clinic is unlikely to be representative of the 24-hour situation. Changes of up to $15 \%$ can occur in $\mathrm{SaO}_{2}$ either spontaneously, or on eating, urinating, and changing posture. ${ }^{23} 24$

Recently, nocturnal hypoxia caused by sleep apnoea has been proposed as a possible extra stimulus for producing secondary polycythaemia and cor pulmonale in patients with CAWO. ${ }^{25} 26$ Intermittent hypoxia appears to be almost as potent a stimulus for erythropoietin production as continuous hypoxia. ${ }^{19} 27$ Proving this hypothesis will be difficult ${ }^{28}$ for two reasons. Firstly, the weighting of the "mean $\mathrm{SaO}_{2}$ " by extra nocturnal hypoxia is unlikely to be simply arithmetic and secondly, it may be that the secondary polycythaemia itself contributes to nocturnal hypoxia. Solving this conundrum will require long-term prospective studies.

Because of the presence of these periods of nocturnal hypoxia we believe it is incorrect to try and estimate whether or not the extra oxygen carriage afforded by a high haematocrit is more than offset by the increased viscosity. This exercise is sometimes done in order to justify phlebotomy. ${ }^{29-32} \mathrm{~A}$ certain rise in the haematocrit might well seem excessive for the degree of daytime arterial desaturation on the grounds that the increased viscosity would actually lead to a diminished oxygen supply to the tissues. However, when the very much lower nocturnal saturations are considered, ${ }^{22} 3334$ one could argue that this rise in the oxygen carrying capacity of the blood was vital for adequate tissue oxygenation at night.

Direct experimentation and computer modelling of the lung ${ }^{35}$ suggest that the arterial hypoxaemia of subjects with normal lungs resident at high altitude is only minimally affected by the extra stress of a fall in mixed venous $\mathrm{Po}_{2}$ from exercise or reduced cardiac output. However similar stress inflicted on patients with hypoxaemia from abnormal lungs at sea level will cause a more marked deterioration in $\mathrm{SaO}_{2}$. Add to this the fluctuating behaviour of lung function in patients with CAWO and it becomes clear why the hypoxia of altitude is an inadequate

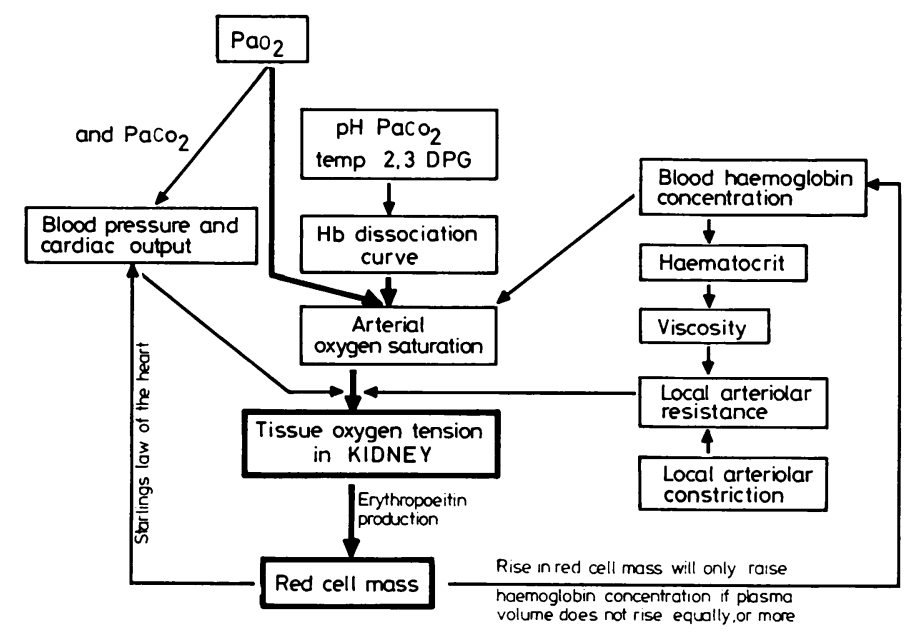

Fig 4 Diagramnatic representation of factors affecting $\mathrm{SaO}_{2} /$ red cell mass relationship. 
model for predicting $\mathrm{SaO}_{2} / \mathrm{RCM}$ relationships in these patients.

A further important factor which actually lowers the true $\mathrm{SaO}_{2}$ is a raised carboxyhaemoglobin level caused by smoking. ${ }^{36-38}$ This not only reduces oxygen delivery to the tissues by titrating away available haemoglobin but also alters the $\mathrm{P}^{50^{37}}$ thus changing the $\mathrm{SaO}_{2}$ and renal $\mathrm{Po}_{2}$ relationship. There is also evidence that smoking can cause supine hypoxaemia. ${ }^{39}$ Smoking appeared to be the only cause of a raised RCM in five smokers studied by Sagone and Balcerzak. ${ }^{36}$ In a larger survey of 22 smokers with mean blood carboxyhaemoglobin levels of $11.6 \%$ Smith and Landaw ${ }^{37}$ found the RCM raised in 14 out of 18 . Unfortunately no assessment was made of postural or nocturnal hypoxia but the RCM did decrease in all five patients who were able to considerably reduce or stop smoking. Similarly Calverley et $a^{38}$ found RCM estimations higher at any given level of $\mathrm{PaO}_{2}$ in 30 smokers than in 17 non-smokers all with cor pulmonale. Furthermore, in 12 of these patients given long-term oxygen therapy, smoking appeared to prevent the expected fall in RCM as had also been observed by Foster et al. ${ }^{40}$

Despite this very real effect from smoking it is not yet possible to state by how much it affects the overall $\mathrm{SaO}_{2} / \mathrm{RCM}$ relationship either at altitude or in hypoxic patients.

\section{What might block the $\mathrm{RCM}$ response?}

Some early explanations for the presumed deficient RCM response to hypoxaemia in patients with CAWO included chronic infection, $\mathrm{CO}_{2}$ retention, and incipient iron deficiency. Iron deficiency was certainly sometimes present, possibly because of recurrent phlebotomy. Failure of the bone marrow to respond, rather than low erythropoietin levels, has been demonstrated, ${ }^{4-8}$ but although iron and total iron binding capacities were measured in these studies, the patients' B12, folate, urea, ESR, liver function tests, and alcohol intake were not recorded. Thus recognised reasons for diminished erythropoiesis were not excluded. It is of interest here that iron deficiency renders the red cells hypochromic but may not prevent the red cell mass and haematocrit from increasing ${ }^{15}$; hence the induction of iron deficiency as a way to control secondary polycythaemia is not advised.

Finally, the association between hypoxia in CAWO and testosterone levels may be an important factor. It has been shown that the serum testosterone level correlates to an extent with the severity of the hypoxia. ${ }^{41}$ Testosterone withdrawal reduces the bone marrow response to hypoxia ${ }^{27} 42$ and thus would alter the $\mathrm{SaO}_{2} / \mathrm{RCM}$ relationship. Whether testosterone levels are similarly depressed at altitude is unknown.

\section{Conclusion}

Given the number of factors involved in the relationship between single measured values of reduced $\mathrm{SaO}_{2}$ and red cell mass it is interesting that the relationship recorded for subjects at altitude is as good as it is.

In CAWO the additional factors causing variability of the $\mathrm{SaO}_{2}$ make it easy to understand that this relationship, particularly at low arterial saturations, is unlikely to match closely that obtained at altitude. Statements about the appropriateness or otherwise of rises in RCM, in the face of hypoxaemia from CAWO, which are based on predictions from altitude data are not justified.

J R STRADLING AND D J LANE Chest Clinic

Churchill Hospital Oxford

\section{References}

1 Wilson RH, Borden CW, Ebert RV. Adaptation to anoxia in chronic pulmonary emphysema. Arch Intern Med 1951; 88:581-90.

2 Hammarsten JF, Whitcomb WH, Johnson PC, Lowell JR. The hematologic adaptation of patients with hypoxia due to pulmonary emphysema. $A m$ Rev Tuberc 1958; 78: 391-8.

3 Simpson T. Anoxia in emphysema. Lancet 1957; 2:105-13.

4 Freedman BJ, Penington DG. Erythrocytosis in emphysema. Br J Haemutol 1963; 9:425-30.

5 Vanier T, Dulfano MJ, Wu C, Desforges JF. Emphysema, hypoxia and the polycythemic response. $N$ Eng $J$ Med 1963; 269:169-78.

6 Gallo RC, Fraimow W, Cathcart RT, Erslev AJ. Erythropoietic response in chronic pulmonary disease. Arch Intern Med 1964; 113:559-68.

7 Ayvazian LF, Richardson DE, Silber R. Erythrokinetic studies during antimicrobial therapy in pulmonary emphysema. Am Rev Respir Dis 1969; 100:305-13.

8 Lertzman M, Israels LG, Cherniack RM. Erythropoiesis and ferrokinetics in chronic respiratory disease Ann Intern Med 1962; 56:821-33.

9 Shaw DB, Simpson T. Polycythaemia in emphysema. QJ Med 1961; 30:135-52.

10 Murray JF. Arterial studies in primary and secondary polycythemic disorders. Am Rev Respir Dis 1965; 92:435-49.

11 Hume R. Blood volume changes in chronic bronchitis and emphysema. BrJ Haematol 1968; 15:131-9.

12 Chan BWB. Polycythaemia in coal miners with chronic lung disease. $\mathrm{Br}$ Med $J$ 1969; 2:349-50. 
13 Cocking JB, Darke CS. Blood volume studies in chronic obstructive non-specific lung disease. Thorax 1972; 27: 44-51.

14 Weil JV, Jamieson G, Brown DW, Grover RF. The red cell mass-arterial oxygen relationship in normal man. Application to patients with chronic obstructive airway disease. J Clin Invest 1968; 47:1627-39.

15 Tura S, Pollycove M, Gelpi AP. Erythrocyte and iron-kinetics in patients with chronic pulmonary emphysema. J Nucl Med 1962; 3:110-27.

16 Harrison BDW. Polycythaemia in a selected group of patients with chronic airways obstruction. Clin Sci 1973; 44:563-70.

17 Harrison BDW, Davis J, Madgwick RG, Evans M. The effects of therapeutic decrease in packed cell volume on the responses to exercise of patients with polycythaemia secondary to lung disease. Clin $\mathrm{Sci}$ Mol Med 1973; 45:833-47.

18 Bert $P$. Sur la richesse en hémoglobine du sang des animaux vivant sur les hauts lieux. C $R$ Acad $S c i$ (Paris) 1882; 94:805-7.

19 Hurtado A, Merino C, Delgado E. Influence of anoxemia on the hemopoietic activity. Arch Intern Med 1945; 75:284-323.

20 Wennesland R, Brown E, Hopper J, et al. Red cell plasma and blood volume in healthy men measured by radiochromium $\left(\mathrm{Cr}^{51}\right)$ cell tagging and haematocrit: influence of age, somatotype and habits of physical activity on the variance after regression of volumes to height and weight combined. J Clin Invest 1959; 38:1065-77.

21 Harris JW, Kellermeyer RW. The red cell. Boston: Harvard University Press, 1970.

22 De Gruchy GC. Clinical haematology in medical practice Third edition. Oxford: Blackwell, 1970.

23 Flick MR, Block AJ. Continuous in-vivo monitoring of arterial oxygenation in chronic obstructive lung disease. Ann Intern Med 1977; 86:725-30.

24 Ward HP, Bigelow DB, Petty TL. Postural hypoxemia and erythrocytosis. Am J Med 1968; 45:880-8.

25 Flenley DC. Clinical hypoxia: causes, consequences, and correction. Lancet 1978; $1: 542-6$.

26 Block AJ, Boysen PG, Wynne JW. The origins of cor pulmonale. A hypothesis. Chest 1979; 75:109.

27 Schooley JC, Mahlmann LJ. Hypoxia and the initiation of erythropoietin production. Blood Cells $1975 ; 1: 429-48$.
28 Flenley DC. Hypoxaemia during sleep. Thorax 1980; 35: $81-4$.

29 Harrison BDW, Gregory RJ, Clark TJH, Scott GW. Exchange transfusion with Dextran 40 in polycythaemia secondary to hypoxic lung disease. $B r$ Med J 1971; 4:713-6.

30 Weisse AB, Moschos CB, Frank MJ, Levinson GE, Cannilla JE, Regan TJ. Hemodynamic effects of staged hematocrit reduction in patients with stable cor pulmonale and severely elevated hematocrit levels. Am J Med 1975; 58:92-8.

31 Dayton LM, McCullough RE, Scheinhorn DJ, Weil JV. Symptomatic and pulmonary response to acute phlebotomy in secondary polycythemia. Chest 1975; 68:785-90.

32 Pearson TC. Who should you treat for polycythaemia Br J Hosp Med 1980; 24:66-73.

33 Trask CH, Cree EM. Oximeter studies on patients with chronic obstructive emphysema awake and during sleep. $N$ Eng J Med 1962; 266:639-42.

34 Douglas NJ, Calverley PMA, Leggett RJE, Brash HM, Flenley DC, Brezinova V. Transient hypoxaemia during sleep in chronic bronchitis and emphysema. Lancet 1979; 1:1-4.

35 West JB. Ventilation-perfusion inequality and overall gas exchange in computer models of the lung. Respir Physiol 1969; 7:88-110.

36 Sagone AL, Balcerzak SP. Smoking as a cause of erythrocytosis. Ann Intern Med 1975; 82:512-5.

37 Smith JR, Landaw SA. Smokers polycythemia. $N$ Engl J Med 1978; 298:6-10.

38 Calverley PMA, McElderry L, Leggett RJE, Flenley DC. Secondary polycythaemia and carboxyhaemoglobin from smoking in hypoxic cor pulmonale. Am Rev Respir Dis 1980; 121:No 4 pt 2118.

39 Strieder DJ, Murphy R, Kazemi H. Mechanism of postural hypoxemia in asymptomatic smokers. $\mathrm{Am}$ Rev Respir Dis 1969; 99:760-6.

40 Foster LJ, Corrigan K, Goldman AL. Effectiveness of oxygen therapy in hypoxic polycythemic smokers. Chest 1978; 73:572-6.

41 Semple PD'A, Beastall GH, Watson WS, Hume R. Serum testosterone depression associated with hypoxia in respiratory failure. Clin Sci 1980;58:105-6

42 Moore LG, McMurtry IF, Reeves JT. Effects of sex hormones on cardiovascular and hematologic responses to chronic hypoxia in rats. Proc Soc Exp Biol Med 1978; 158:658-62. 